\title{
Study on the environmental conditions and trends of Changli Golden Coast Nature Reserve
}

\author{
Zhao-shuang Zeng ${ }^{1}$, Xin-yang $\mathrm{Li}^{2}$, Zi-chu Fan ${ }^{3}$, Dan $\mathrm{Yu}^{4}$ \\ ${ }^{1}$ Qinhuangdao Marine Environmental Monitoring Central Station, Hebei Qinhuangdao \\ ${ }^{2}$ Qinhuangdao Marine Environmental Monitoring Central Station, Hebei Qinhuangdao \\ ${ }^{3}$ Qinhuangdao Marine Environmental Monitoring Central Station, Hebei Qinhuangdao \\ ${ }^{4}$ Qinhuangdao Marine Environmental Monitoring Central Station, Hebei Qinhuangdao
}

\begin{abstract}
KEYWORD: Changli Golden Coast; Marine environmental quality; Trends
ABSTRACT: Based on the monitoring results of Changli Golden Coast Nature Reserve (2009-2014), conditions and trends of seawater and Sediment quality in this area were analyzed. The results showed that: seawater and sediment quality in this area as a whole is better, however, in some years inorganic nitrogen in local area is high. Since there is a large number of farming areas near the reserve, the increasing pollutant emissions has a potential impact on the ecological environment of this area. The departments concerned should strengthen the management of farming areas, strictly control the scale of farming.
\end{abstract}

\section{INTRODUCTION}

Changli Golden Coast Nature Reserve is one of the first five national marine nature reserves approved by the state Department on September 30, 1990 .The reserve is located in the northeastern coast Changli County, Qinhuangdao, Hebei Province. It is an area of 300 square kilometers, land and sea. The land area is 91.5 square kilometers. Marine parts are 20.85 square kilometers. Shoreline length is 47.22 kilometers. The main objects of protection are the sandy coast natural landscape and the ecological environment and natural resources made of dunes, sandbar, lagoon, forest and marine organisms. The reserve is a typical coast to study marine dynamic processes and change of land and sea. It has important ecological value, scientific value and ornamental value. As China's most beautiful coast and only eight national marine nature reserves, marine environmental quality in Golden Coast Nature Reserve is a focus of attention of government and public.

Since 2009, organized by Hebei Provincial Oceanic Administration, Hebei Province Marine Environment Monitoring Center and Management Office of Changli Golden Coast Nature Reserve conducted long-term continuous monitoring in the sea parts of the Reserve, basically got the marine ecological system condition of Changli Golden Coast Nature Reserve, laid the foundation for the assessment of ecosystem health status, degree of ecological monitoring system changes and tendency.

\section{MATERIALS AND METHODS}

\section{Materials}

Environment quality of Changli Golden Coast Nature Reserve has been investigated by the Marine Environment Monitoring Center of Hebei Province and Changli Golden Coast Nature Reserve Management Department from 2009 to 2014.There were 8 monitoring stations in the Changli Golden Coast National Nature. Among them, each 4 stations were set up both in the core area and the buffer area. The specific positions are shown in Figure 1. 


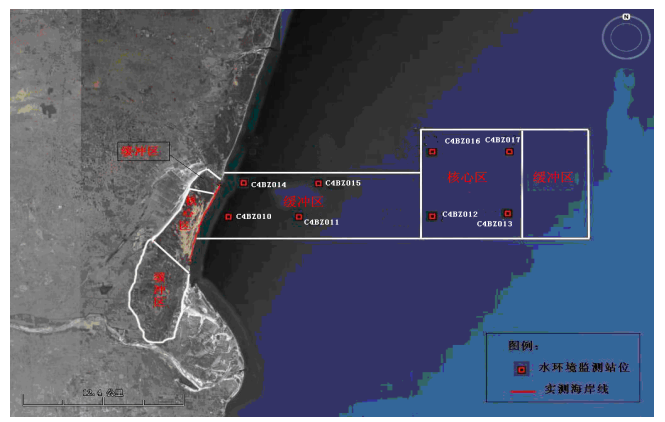

Fig.1. Distribution of the survey stations

The monitoring frequency is carried out annually in August. Monitoring indicators include DO(dissolved oxygen), COD( chemical oxygen demand), $\mathrm{pH}$, DIN (dissolved inorganic nitrogen), DIP (dissolved inorganic phosphorus), petroleum of seawater, and sulfide, TOC(total organic carbon) of sediment.

\section{Methods}

Analysis methods of seawater and sediment samples are according to "The specification for marine monitoring" (GB17378-2007). We use single factor method to carry out water quality evaluation by $\mathrm{pH}, \mathrm{DO}, \mathrm{COD}$, DIN, DIP, petroleum, and select TOC and sulfide as the assessment of sediment quality factors. We use the first level in "Sea water quality standard" (GB3097-1997) and "Marine sediment quality" (GB18668-2002) to evaluate the environment quality of Changli Golden Coast National Nature.

\section{RESULT AND DISCUSSION}

\section{water quality}

The seawater monitoring results of Changli Golden Coast Nature Reserve from 2009 to 2014 are shown in Table 1

Table 1 . The sea water monitoring results

\begin{tabular}{ccccccc}
\hline & $\mathrm{pH}$ & $\begin{array}{c}\mathrm{COD} / \mathrm{mg} . \mathrm{L}^{-} \\
1\end{array}$ & $\mathrm{DO} / \mathrm{mg} . \mathrm{L}^{-1}$ & $\mathrm{DIN} / \mu \mathrm{g} . \mathrm{L}^{-1}$ & $\mathrm{DIP} / \mu \mathrm{g} . \mathrm{L}^{-1}$ & $\begin{array}{c}\text { petroleum } \\
/ \mu \mathrm{g} . \mathrm{L}^{-1}\end{array}$ \\
\hline 2009 & 8.1 & 1.50 & 6.60 & 69.0 & 3.30 & 41.5 \\
2010 & 8.1 & 1.27 & 7.04 & 120 & 4.58 & 20.0 \\
2011 & 8.4 & 1.29 & 8.35 & 51.0 & 3.66 & 32.8 \\
2012 & 8.3 & 1.43 & 6.97 & 498 & 7.00 & 20.0 \\
2013 & 8.1 & 1.40 & 7.00 & 74.6 & 4.00 & 18.6 \\
2014 & 8.1 & 1.44 & 7.25 & 155 & 5.80 & 18.2 \\
\hline
\end{tabular}

\section{pH}

From 2009 to 2014, the range of $\mathrm{pH}$ in Changli Golden Coast Nature Reserve was $8.1 \sim 8.4$. The interannual variation is shown in Figure 2. 


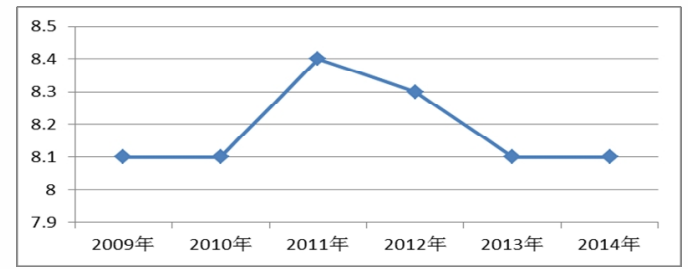

Figure 2.The interannual variation of $\mathrm{pH}$

The interannual variation of $\mathrm{pH}$ is small. The highest $\mathrm{pH}$ appeared in 2011, and the lowest one appeared in 2009, 2010, 2013, 2014. The annual average was 8.18. Each year pH satisfies the first level of seawater quality standards.

\section{COD}

From 2009 to 2014, the range of COD in Changli Golden Coast Nature Reserve was 1.27 1.50 $\mathrm{mg} . \mathrm{L}^{-1}$. The interannual variation is shown in Figure 3.

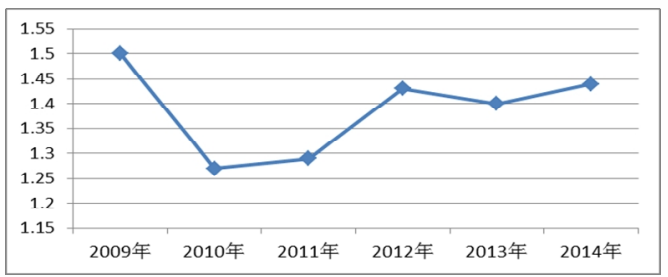

Figure 3.The interannual variation of COD(unit: $\mathrm{mg} . \mathrm{L}^{-1}$ )

The highest COD appeared in 2009, and the lowest one appeared in 2010. The annual average was $1.39 \mathrm{mg} \cdot \mathrm{L}^{-1}$. COD pollution index of each year was less than 1.0. It satisfies the first level of seawater quality standards. Compared with the area monitoring data in 1999, the COD content decreased slightly, and the decline was $5.4 \%$.

\section{DO}

From 2009 to 2014, the range of DO in Changli Golden Coast Nature Reserve was 6.60 8.35mg. $\mathrm{L}^{-1}$. The interannual variation is shown in Figure 4.

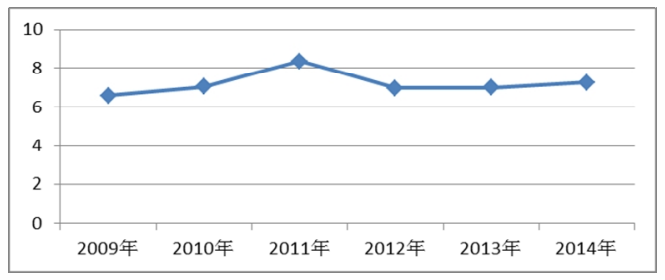

Figure 4.The interannual variation of DO(unit: $\left.\mathrm{mg} . \mathrm{L}^{-1}\right)$

The highest DO appeared in 2011, and the lowest one appeared in 2009. The annual average was 7.20mg. $\mathrm{L}^{-1}$. DO pollution index of each year was less than 1. It satisfies the first level of seawater quality standards. Compared with the area monitoring data in 1999, the DO content increased slightly, and the increase was $1.4 \%$.

\section{DIN}

From 2009 to 2014, the range of DIN in Changli Golden Coast Nature Reserve was $51.0 \sim 498 \mu \mathrm{g} . \mathrm{L}-1$. The interannual variation is shown in Figure 5. 


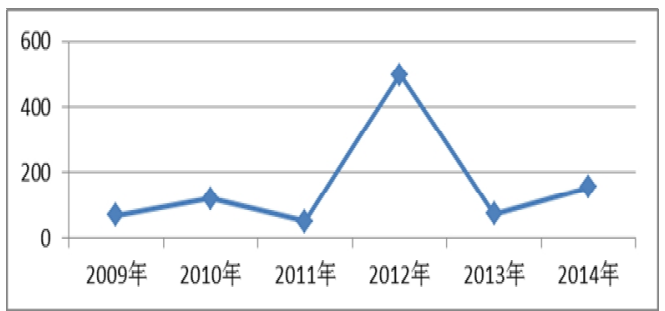

Figure 5.The interannual variation of DIN(unit: $\mu \mathrm{g} . \mathrm{L}^{-1}$ )

The highest DIN appeared in 2012, and the lowest one appeared in 2011. The annual average was $161 \mu \mathrm{g} . \mathrm{L}^{-1}$. DIN pollution index of 2012 was more than 1.0, and that of other years were less than 1 , which satisfies the first level of seawater quality standards. Compared with the area monitoring data in 1999 , the DO content decreased, and the decline was $55.6 \%$.

\section{DIP}

From 2009 to 2014, the range of DIP in Changli Golden Coast Nature Reserve was 3.30 7.00 $\mu \mathrm{g} . \mathrm{L}^{-1}$. The interannual variation is shown in Figure 6.

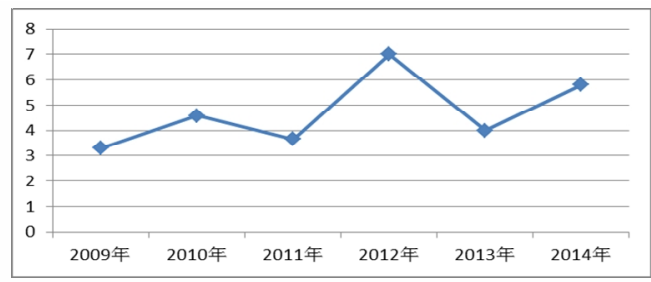

Figure 6.The Interannual variation of DIP(unit: $\mu \mathrm{g} . \mathrm{L}^{-1}$ )

The highest DIP appeared in 2012, and the lowest one appeared in 2009. The annual average was $4.72 \mu \mathrm{g} . \mathrm{L}^{-1}$. DIP pollution index of each year was less than 1. It satisfies the first level of seawater quality standards. Compared with the area monitoring data in 1999, the DO content decreased greatly, and the decline was $83.8 \%$.

\section{Petroleum}

From 2009 to 2014, the range of petroleum in Changli Golden Coast Nature Reserve was 18.2 41.5 $\mu \mathrm{g} . \mathrm{L}^{-1 .}$ The interannual variation is shown in Figure 7.

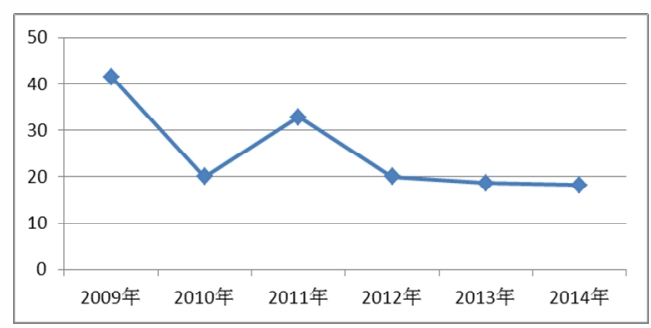

Figure 7.The interannual variation of petroleum (unit: $\mu \mathrm{g} . \mathrm{L}^{-1}$ )

The highest petroleum appeared in 2009, and the lowest one appeared in 2014. The annual average was $25.2 \mu \mathrm{g} . \mathrm{L}^{-1}$. Petroleum pollution index of each year was less than 1 . It satisfies the first level of seawater quality standards.

\section{sediment quality}

The sediment monitoring results of Changli Golden Coast Nature Reserve from 2009 to 2014 are shown in Table 2 
Table 2. The sediment monitoring results

\begin{tabular}{ccccccc}
\hline & 2009 & 2010 & 2011 & 2012 & 2013 & 2014 \\
\hline $\begin{array}{c}\text { TOC } \\
(\%)\end{array}$ & 0.14 & 0.11 & 0.143 & 0.236 & 0.228 & 0.291 \\
sulfide $\left(\times 10^{-6}\right)$ & 12.1 & 13.2 & 70.4 & 40.2 & 38.4 & 39.6 \\
\hline
\end{tabular}

TOC

From 2009 to 2014, the range of TOC in Changli Golden Coast Nature Reserve was 0.11\% $0.291 \%$. The interannual variation is shown in Figure 8.

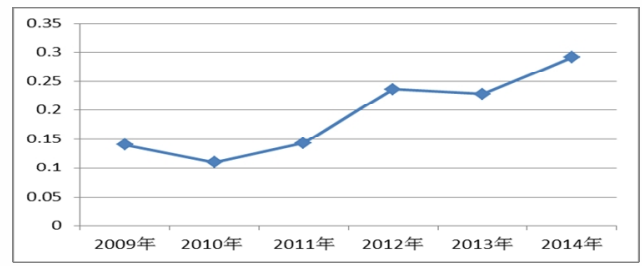

Figure 8.The interannual variation of TOC(unit:\%)

The highest TOC appeared in 2014, and the lowest one appeared in 2010. The annual average was $0.190 \%$. TOC pollution index of each year was less than 1 . It satisfies the first level of sediment quality standards. Compared with the area monitoring data in 2002, the TOC content decreased greatly, and the decline was $91.8 \%$.

\section{Sulfide}

From 2009 to 2014, the range of sulfide in Changli Golden Coast Nature Reserve was 12.01 70.4 $\times 10^{-6}$. The interannual variation is shown in Figure 9 .

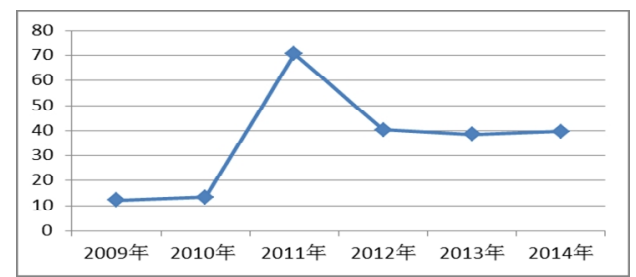

Figure 9.The interannual variation of sulfide (unit: $10^{-6}$ )

The highest sulfide appeared in 2011, and the lowest one appeared in 2009. The annual average was $35.7 \times 10^{-6}$. Sulfide pollution index of each year was less than 1 . It satisfies the first level of sediment quality standards. Compared with the area monitoring data in 2002, the TOC content decreased greatly, and the decline was $87.99 \%$.

\section{RESULTS AND SUGGESTION}

\section{Results}

The seawater and sediment environment quality of Changli Golden Coast Nature Reserve is good as a whole. Except DIN in 2012, all the other monitoring indicators include DO,COD, pH, DIN, DIP, petroleum of sea water, as well as sulfide, TOC of sediment indicators in 2009 2014, were satisfied the first level of quality standards. Compared with the historical data, DO content increased, while COD, DIN, DIP, TOC, sulfide content decreased. Some indicators even decreased by over $83.8 \%$, 
such as DIP, DIN and sulfide. This indicates that the seawater and sediment environment quality of Changli Golden Coast Nature Reserve has improved. Since 2013, due to the increase of the scallop culture surrounding nature reserve sea areas, COD, DIN, DIP contents are increasing. In particular, the content of DIN was up to $107.1 \%$.It has potential impacts on the ecological environment of nature reserve.

\section{Suggestion}

We should carry out scientific long-term planning for the nature reserve and the adjacent sea area. With coordination of development and protection, we should use sea areas rationally and ecologically, especially control the scale of farming strictly and strengthen the protection of the adjacent area which is used for sea scallop culture management.

\section{REFERENCES}

[1] Zhao-guang Jin, Hong-wei Bao. Environmental pressure and Countermeasures of Changli Golden Coast Nature Reserve. Journal of environmental Management College of China 2008.6; $18(2)$.

[2]Tian Li. Changli Golden Coast Nature Reserve. Chinese and coastal-zone development 1991; 11 [3]Jing-rong Hu. Discussion on the construction of Changli Golden Coast Nature Reserve. Ocean and coastal-zone development 1991; 03 